\title{
Modulation of Human Intestinal Epithelial Cell IL-8 Secretion by Human Milk Factors
}

\author{
ERIKA C. CLAUD, TOR SAVIDGE, AND W. ALLAN WALKER \\ Developmental Gastroenterology Laboratory, Pediatric Gastroenterology and Nutrition, Massachusetts \\ General Hospital, Charlestown, Massachusetts 02129, U.S.A.
}

\begin{abstract}
Necrotizing enterocolitis (NEC) seems to result from the inflammatory response of an immature intestine. Human milk is protective against NEC via an unknown mechanism. We hypothesized that specific factors found in human milk would decrease stimulated IL-8 secretion in intestinal epithelial cells. HT29cl19A and Caco2 cells were compared with the fetal human primary intestinal epithelial cell line $\mathrm{H} 4$ and temperaturesensitive conditionally immortalized fetal human intestinal (tsFHI) cells. Cells were pretreated with transforming growth factor- $\beta$ (TGF- $\beta$ ), erythropoietin (Epo), IL-10, or epidermal growth factor (EGF) at physiologic concentrations before stimulation with tumor necrosis factor- $\alpha$ (TNF- $\alpha$ ) or IL- $1 \beta$, and then IL-8 was measured by ELISA. The fetal cells produced significantly more IL- 8 when stimulated by TNF- $\alpha$ or IL- $1 \beta$. There were also differences in the pattern of alteration of IL- 8 secretion by human milk factors. In HT29-c119A cells, IL-10 inhibited TNF- $\alpha-$ stimulated IL- 8 secretion by $52 \%$, and EGF increased secretion by $144 \%$. In H4 cells, TGF- $\beta 1$ and Epo inhibited TNF- $\alpha-$ stimulated IL-8 secretion to control levels, and EGF increased secretion by $29 \%$. IL- $1 \beta$-stimulated IL- 8 secretion was inhibited
\end{abstract}

ABSTRACT

$25 \%$ by TGF- $\beta 1$ in Caco 2 cells and in $\mathrm{H} 4$ cells was inhibited by TGF- $\beta 1$, Epo, and TGF- $\beta 2$. TsFHI cells confirmed H4 cell results. Fetal human enterocytes have an exaggerated IL-8 secretion in response to TNF- $\alpha$ and IL- $1 \beta$. TGF- $\beta$ and Epo decrease this stimulated IL- 8 secretion, which may partially explain the protective effect of human milk in NEC. (Pediatr Res 53: 419-425, 2003)

\section{Abbreviations}

DMEM, Dulbecco's modified Eagle's medium

EGF, epidermal growth factor

Epo, erythropoietin

FBS, fetal bovine serum

IEC, intestinal epithelial cell

NEC, necrotizing enterocolitis

NF- $\boldsymbol{B}$, nuclear factor $\kappa \mathrm{B}$

SV40, simian virus 40

TGF- $\boldsymbol{\beta}$, transforming growth factor- $\beta$

TNF, tumor necrosis factor

TsFHI, temperature-sensitive fetal human intestinal cells
Evidence suggests that the intestinal epithelium is an active participant in gastrointestinal host defense and that intestinal epithelial-microbial interactions are developmentally regulated (1-4). Children are more susceptible to severe diarrhea from rotavirus and vibrio cholera toxin than are adults (5), and animal models have demonstrated prolonged rotavirus shedding and an increased secretory response to cholera toxin in neonatal compared with adult rats (6). Necrotizing enterocolitis (NEC) is another disease of intestinal maturation and microbial interaction. The primary risk factor for this disease is prematurity, and although the pathophysiology of this disease is not completely understood, an exaggerated inflammatory response to intestinal bacteria is a possible contributing mechanism (7).

Received August 9, 2002; accepted November 15, 2002.

Correspondence: W. Allan Walker, M.D., Developmental Gastroenterology Laboratory, Massachusetts General Hospital, 114 16th Street (114-3503), Charlestown, MA 02129, U.S.A., e-mail: wwalker@partners.org

This work was supported by NIH grants T32-HD07466-07 (E.C.), R01-HD-31852, R37-HD12437, P01-DK33506, and P30-DK40561.

DOI: 10.1203/01.PDR.0000050141.73528.AD
Several issues make the preterm intestine increasingly susceptible to microbial interaction. Decreased intestinal blood flow regulation, gastric acid production, levels of protective mucus, proteolytic enzyme activity, intestinal motility, and levels of $\operatorname{sIgA}$ are contributing factors. In addition, increased intestinal permeability enhances susceptibility (8). It is known that the fetal intestine is exposed to amniotic fluid containing hormones and peptides that may have a role in intestinal maturation. Preterm infants may not have completed this maturation process when colonized by bacteria and initially fed. At this stage, the fetal intestine is normally protected in its sterile environment and may not be prepared to respond to bacterial interaction.

Human milk seems to be protective against intestinal inflammation. A study of chemical colitis in rats demonstrated decreased myeloperoxidase activity in animals fed human milk (9). A clinical study by Lucas and Cole (10) demonstrated a decreased incidence of NEC in human milk-fed preterm infants compared with formula-fed infants. Human milk contains 
several factors that may decrease the incidence of NEC. It contains factors to decrease microbial interaction with the intestinal epithelium such as lysozyme, lactoferrin, polymeric IgA, and oligosaccharides (11-13). In addition, it contains anti-inflammatory factors such as soluble tumor necrosis factor (TNF) receptor, IL-1 receptor antagonist, and acetylhydrolase (14). It also contains factors such as transforming growth factor- $\beta$ (TGF- $\beta$ ) and epidermal growth factor (EGF) that limit intestinal injury by stimulating intestinal repair through increased cell restitution, growth, and inhibition of apoptosis (15).

Enterocytes are active participants in host defense. In response to stimuli, enterocytes can release cytokines such as IL-6, TNF- $\alpha$, and IL-8 (1). Specifically, we have previously shown that compared with adult cells, immature or undifferentiated intestinal epithelial cells (IEC) have increased IL-8 secretion in response to products associated with bacterial challenge such as lipopolysaccharide with butyrate and IL-1 $\beta$ (2). This exaggerated inflammatory response may have a role in NEC (16). Histopathology sections of intestine from infants with NEC reveal evidence of necrosis and inflammation (17, 18). Neutrophils in particular seem to have a central role in the intestinal injury, and it has been shown that neutrophil depletion by vinblastine eliminated intestinal injury in a rat model of NEC (19).

IL-8 is a chemokine that stimulates migration of neutrophils from intravascular to interstitial sites and can directly activate neutrophils and regulate the expression of neutrophil adhesion molecules (20-22). Thus, by recruiting and activating immune cells, IL-8 may play an important role in inflammation. Previous studies have shown that concentrations of serum IL- 8 were significantly elevated in severe cases of NEC from its onset through the first $24 \mathrm{~h}$ (16). Surgical specimens of intestine from infants with acute NEC show up-regulation of IL-8 mRNA throughout the serosa, muscularis, and intestinal epithelium compared with those with other inflammatory conditions or those without disease (23).

On the basis of these previous observations, we studied the effect of specific factors in human milk on IL-8 secretion. We chose to test four factors-TGF $\beta$, erythropoietin (Epo), IL-10, and EGF - that have been shown to be protective against NEC and/or have anti-inflammatory effects in other models (24-28). We hypothesized that at physiologic concentrations, these factors would decrease IL-8 secretion induced by inflammatory stimuli in IEC.

\section{METHODS}

Materials. TNF- $\alpha$, IL- $1 \beta$, TGF- $\beta$, Epo, EGF, IL-10, goat antihuman IL-8 antibody, and recombinant human IL-8 were obtained from R\&D Systems (Minneapolis, MN, U.S.A.). Rabbit anti-human IL-8 antibody was obtained from Endogen (Woburn, MA, U.S.A.). Horseradish peroxidase goat antirabbit IgG antibody was obtained from Biosource (Camarillo, CA, U.S.A.). 2,2' Azino-Bis (3-Ethylbenz-thiazoline-6sulfonic acid) was obtained from Sigma Chemical Co. (St. Louis, MO, U.S.A.).

IEC lines. Four human IEC lines were used in these studies: HT29-cl19A, Caco2, H4, and temperature-sensitive fetal hu- man intestinal cells (tsFHI). HT29-cl19A cells originate from the subcloning of an adult colonic adenocarcinoma cell line and display a more differentiated phenotype than the original HT29 cells (29). Cells were cultured in Dulbecco's modified Eagle's medium (DMEM) with $10 \%$ heat-inactivated fetal bovine serum (FBS), $50 \mathrm{U} / \mathrm{mL}$ penicillin, and $50 \mu \mathrm{g} / \mathrm{mL}$ streptomycin. Caco2 cells also originate from an adult colonic adenocarcinoma cell line. Cells were cultured in DMEM with $10 \%$ heat-inactivated FBS, $1 \%$ glutamine, $1 \%$ sodium pyruvate, $1 \%$ amino acids, $1 \%$ HEPES, $50 \mathrm{U} / \mathrm{mL}$ penicillin, 50 $\mu \mathrm{g} / \mathrm{mL}$ streptomycin, and $0.2 \mathrm{U} / \mathrm{mL}$ insulin. $\mathrm{H} 4$ cells are a human fetal nontransformed primary small IEC line that has previously been characterized in this laboratory (30). These cells do not form tight junctions or polarize. Cells were cultured in DMEM with 10\% heat-inactivated FBS, $1 \%$ glutamine, $1 \%$ sodium pyruvate, $1 \%$ amino acids, $1 \%$ HEPES, 50 $\mathrm{U} / \mathrm{mL}$ penicillin, $50 \mu \mathrm{g} / \mathrm{mL}$ streptomycin, and $0.2 \mathrm{U} / \mathrm{mL}$ insulin. These three cell lines were grown at $37^{\circ} \mathrm{C}$ in a $5 \% \mathrm{CO}_{2}$ atmosphere.

TsFHI cells are a human fetal small IEC line transformed with a temperature-sensitive simian virus 40 (SV40) large tumor antigen. These cells proliferate at $32^{\circ} \mathrm{C}$, but when transferred to $37^{\circ} \mathrm{C}$, the SV40 antigen breaks down, leading to growth arrest and acquisition of an enterocyte-like phenotype, although they remain morphologically immature and do not form tight junctions or polarize (31). These cells were provided for our studies by Dr. Andrea Quaroni (Department of Biology, Cornell University, Ithaca, NY, U.S.A.). These cells were grown at $32^{\circ} \mathrm{C}$ in growth medium consisting of OptiMEM I supplemented with $4 \%$ heat-inactivated FBS, $10 \mathrm{ng} / \mathrm{mL}$ EGF, $2 \mathrm{mM}$ glutamine, $2 \mathrm{mM}$ L-alanyl-glutamine (GlutaMAX I), 10 $\mathrm{mM}$ HEPES, $50 \mathrm{U} / \mathrm{mL}$ penicillin, and $50 \mu \mathrm{g} / \mathrm{mL}$ streptomycin. When confluent, they were transferred to $37^{\circ} \mathrm{C}$ and medium consisting of DMEM supplemented with $7 \%$ heat-inactivated FBS, 2 mM glutamine, 2 mM GlutaMAX I, 10 mM HEPES, 50 $\mathrm{U} / \mathrm{mL}$ penicillin, and $50 \mu \mathrm{g} / \mathrm{mL}$ streptomycin. Cells were then used after an additional $7 \mathrm{~d}$.

Effect of human milk factors on IL-8 secretion. Cells were grown to confluence in 96-well plates to facilitate testing of multiple conditions. Medium was then changed, and cells were pretreated with factors in question for $24 \mathrm{~h}$ at physiologic concentrations found in human milk; previous dose-response experiments with these factors also showed that these doses gave the maximal effects-TGF- $\beta 30 \mathrm{ng} / \mathrm{mL}(32,33)$, Epo $0.1 \mathrm{U} / \mathrm{mL}(34,35), \mathrm{IL}-1010 \mathrm{ng} / \mathrm{mL}(36,37)$, EGF $100 \mathrm{ng} / \mathrm{mL}$ $(38-40)$. On the basis of previous dose-response and time course data, cells were then treated with either TNF- $\alpha 10$ $\mathrm{ng} / \mathrm{mL}$ for $6 \mathrm{~h}$ or IL- $1 \beta 1 \mathrm{ng} / \mathrm{mL}$ for $24 \mathrm{~h}$ (36). Comparable cell viability under these pretreatment and treatment conditions was confirmed in initial assays by 3-[4,5-Dimethylthyazol-2-y]-2, 5-diphenykltetrazolium bromide cytotoxicity assay. H4 cell responses to TNF- $\alpha$ were compared with HT29-cl19A cells, as Caco 2 cells have previously been shown not to respond to TNF- $\alpha$ (41). H4 cell responses to IL- $1 \beta$ were compared with Caco 2 cells as differentiated HT29 cells have been previously shown not to respond to IL-1 $\beta$ (42). Supernatants were collected for IL-8 determination and stored at $-20^{\circ} \mathrm{C}$. Cell lysates were obtained for measurement of protein concentration. 
IL-8 measurement. IL-8 concentration was measured by an ELISA as described by McCormick (43). Briefly, 96-well plates (Nunc Maxisorp) were coated overnight with $8 \mu \mathrm{g} / \mathrm{mL}$ goat anti-human IL-8 polyclonal antibody. The plate was then washed (PBS plus 5\% neonatal goat serum, 1\% Tween 20 diluted $1: 10$ ) and incubated with samples at $37^{\circ} \mathrm{C}$. After a second wash, the plate was incubated with $8 \mu \mathrm{g} / \mathrm{mL}$ rabbit antihuman IL-8 antibody. The plate was washed again and incubated with horseradish peroxidase goat anti-rabbit IgG 80 $\mathrm{ng} / \mathrm{mL}$. Finally, the plate was washed and incubated with 2,2' Azino-Bis (3-Ethylbenz-thiazoline-6-sulfonic acid). The absorbance was measured at OD 405. Samples were run in quadruplicate, and IL-8 values were normalized to measured protein concentration to allow comparison among cell types.

Protein concentration determination. For protein concentration determination, cells were lysed for $30 \mathrm{~min}$ on ice in the 96-well plate with $40 \mu \mathrm{L} /$ well lysis buffer consisting of $1 \%$ Nonidet P-40, $150 \mathrm{mM} \mathrm{NaCl}, 1 \times$ PBS, $20 \mathrm{mM}$ EDTA, $20 \mathrm{mM}$ EGTA, $4 \mathrm{mM} \mathrm{Na}_{3} \mathrm{VO}_{4}$, and $40 \mathrm{mM} \mathrm{NaF}$. After centrifugation, $5 \mu \mathrm{L} /$ well lysate was used for the BioRad DC Protein Assay as per the manufacturer's protocol.

Statistical analysis. Statistical analysis was reviewed with a statistician. Results are presented as mean values of IL-8 $\mathrm{pg} / \mathrm{mg}$ protein \pm SEM. Statistical significance was evaluated using two-tailed $t$ test. $P<0.05$ was considered statistically significant.

\section{RESULTS}

Comparison of IL-8 secretion in fetal and adult IEC. The human fetal primary IEC line, H4, was compared with the adult cell lines HT29-cl19A and Caco2. Cells were treated with either TNF- $\alpha$ or IL- $1 \beta$. Unstimulated H4 cells secreted 36000 $\pm 7000 \mathrm{pg} / \mathrm{mg}$ protein IL-8, whereas stimulated H4 cells secreted $71000 \pm 10000 \mathrm{pg} / \mathrm{mg}$ protein IL-8 in response to TNF- $\alpha$. In contrast, unstimulated HT29-cl19A cells secreted significantly less IL-8, only $336 \pm 93 \mathrm{pg} / \mathrm{mg}$ protein, and 5030 $\pm 485 \mathrm{pg} / \mathrm{mg}$ protein in response to TNF- $\alpha(p<0.05, n \geq 4$; Fig. 1). Similarly, stimulated H4 cells secreted $346000 \pm$ $49000 \mathrm{pg} / \mathrm{mg}$ protein of IL-8 in response to IL- $1 \beta$, whereas Caco 2 cells secreted significantly smaller baseline IL-8 (279 $\pm 79 \mathrm{pg} / \mathrm{mg}$ protein) and stimulated IL-8 levels (3 $350 \pm$ $330 \mathrm{pg} / \mathrm{mg}$ protein) in response to IL- $1 \beta$ ( $p<0.05, n \geq 4$; Fig. 1).

Effect of human milk factors on IL-8 production in response to $\boldsymbol{T N F}-\boldsymbol{\alpha}$. To determine the effect of the human milk factors, we pretreated H4 and HT29-cl19A cells with each of the factors for $24 \mathrm{~h}$ before the addition of TNF- $\alpha$. IL- 8 concentration was measured by ELISA and normalized to cell protein concentration to allow comparison among cell lines. However, for any given cell line, protein concentration was comparable for all wells, ruling out an alteration in overall protein synthesis as an explanation of the effects. Analysis without correction for protein did not change the results for any given cell line. As outlined in the methods section, concentrations comparable to physiologic levels found in human milk were used for each factor. As TGF- $\beta 2$ is the predominant isoform in human milk, both TGF- $\beta 1$ and TGF- $\beta 2$ were tested (44).

As shown in previous studies (36), IL-10 significantly inhibited IL- 8 secretion in HT29-cl19A cells by $52 \%$ from 5030 $\pm 490 \mathrm{pg} / \mathrm{mg}$ protein to $2400 \pm 440 \mathrm{pg} / \mathrm{mg}$ protein $(p<0.05$, $n \geq 4$ ). No other factor had an inhibitory effect in this cell line.

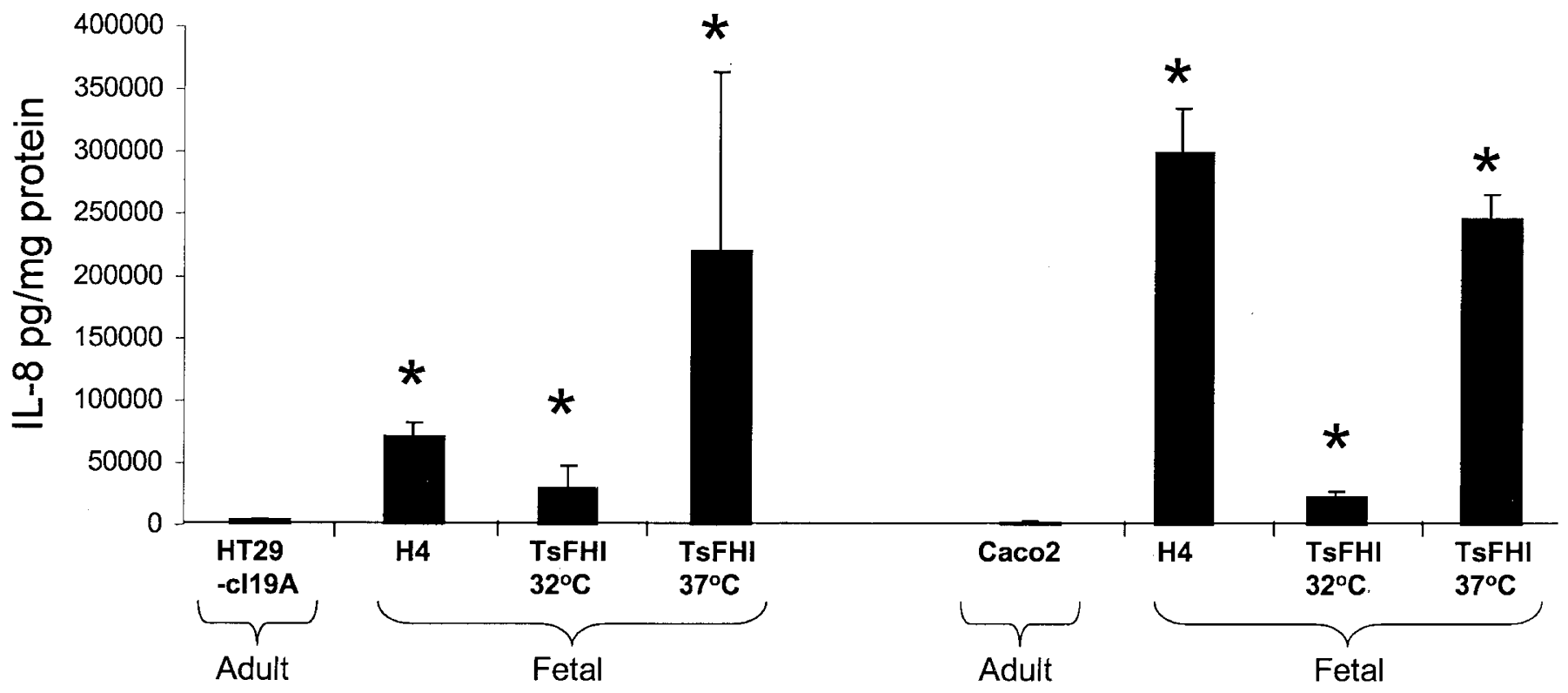

TNFalpha

IL-1 beta

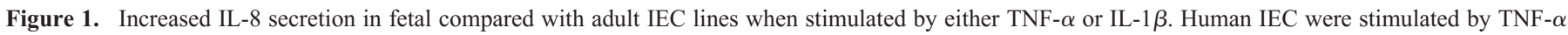

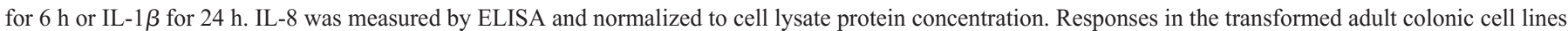

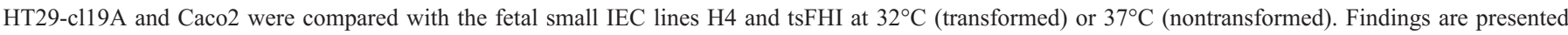
$\pm \mathrm{SEM} ; n \geq 4$. $*$ Statistical significance at $p<0.05$ compared with the adult cell line. 
EGF significantly increased IL-8 secretion by $144 \%$ to 12000 $\pm 2400 \mathrm{pg} / \mathrm{mL}(p<0.05, n \geq 4)$ (Fig. $2 a)$.

In contrast, TNF- $\alpha$-induced IL- 8 secretion in $\mathrm{H} 4$ cells was completely inhibited by TGF- $\beta 1$ from $71000 \pm 10000 \mathrm{pg} / \mathrm{mg}$ protein to control levels of $34000 \pm 3500 \mathrm{pg} / \mathrm{mg}$ protein and by Epo to $41000 \pm 3700 \mathrm{pg} / \mathrm{mg}$ protein $(p<0.05, n \geq 4)$. IL-10, although decreasing IL-8 production, did not have a statistically significant effect. Again, EGF significantly increased IL-8 secretion by $29 \%$ to $92000 \pm 10000$ (Fig. 2b).

Effect of human milk factors on IL-8 production in response to IL-1 $\boldsymbol{\beta}$. As above, $\mathrm{H} 4$ and $\mathrm{Caco} 2$ cells were pretreated with factors for $24 \mathrm{~h}$ before the addition of IL- $1 \beta$. In Caco 2 cells, TGF- $\beta 1$ decreased IL- 8 secretion by $25 \%$ from $3350 \pm 330 \mathrm{pg} / \mathrm{mg}$ protein to $2500 \pm 400 \mathrm{pg} / \mathrm{mg}$ protein $(p$ $<0.05, n \geq 4$; Fig. $3 a$ ). No other significant growth factor effects were observed. In 44 cells, TGF- $\beta 1$ had an even greater inhibitory effect of $63 \%$ from $346000 \pm 49000 \mathrm{pg} / \mathrm{mg}$ protein to $129000 \pm 29000 \mathrm{pg} / \mathrm{mg}$ protein $(p<0.05, n \geq 4)$. In addition, Epo decreased IL-8 secretion $43 \%$ to $196000 \pm$ $21000 \mathrm{pg} / \mathrm{mg}$ protein, and TGF- $\beta 2$ decreased IL- 8 secretion $39 \%$ to $212000 \pm 19000 \mathrm{pg} / \mathrm{mg}$ protein $(p<0.05, n \geq 4$; Fig. $3 b)$.

Effect of human milk factors on IL-8 production in tsFHI cells. TsFHI cells were used to confirm results noted in $\mathrm{H} 4$ cells. This cell line is unique in that it is transformed by the
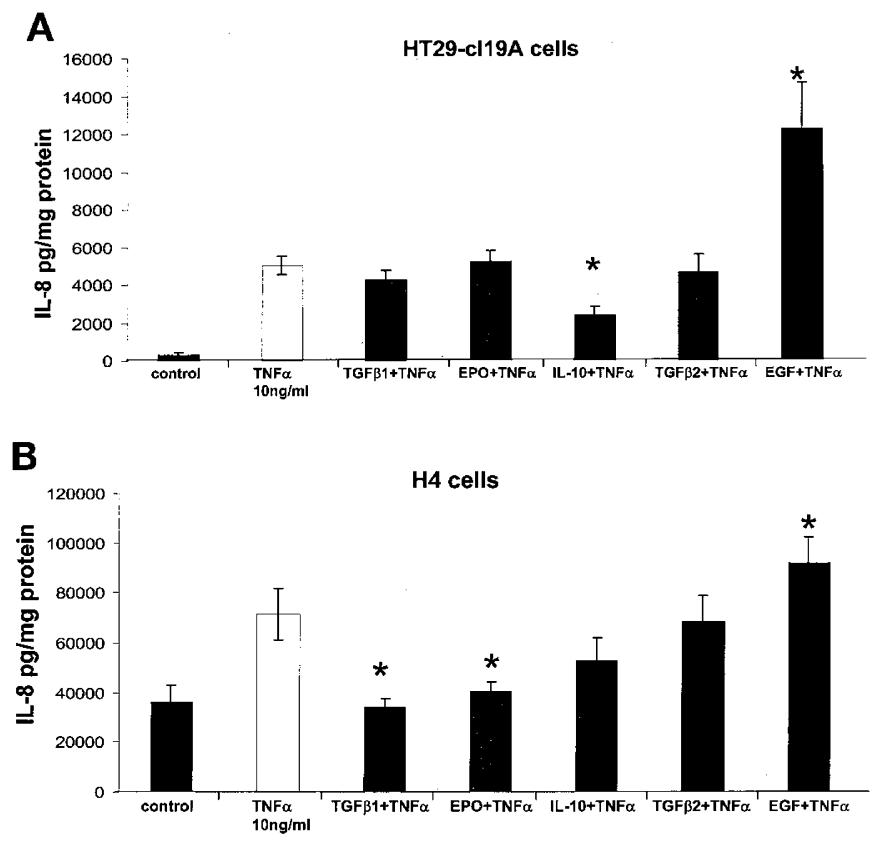

Figure 2. Effect of the human milk factors on TNF- $\alpha$-stimulated IL-8 secretion by human IEC. Cells were pretreated with one of five human milk factors for $24 \mathrm{~h}$ before stimulation with TNF- $\alpha(10 \mathrm{ng} / \mathrm{mL}$ for $6 \mathrm{~h})$. IL-8 was measured by ELISA and compared with measured protein concentrations from cell lysates. Findings are presented \pm SEM; $n \geq 4$. (a) Results in the transformed adult colonic cell line HT29-cl19A. *Statistical significance at $p$ $<0.05$ for inhibition by IL-10 and accentuated stimulation by EGF of TNF- $\alpha$-induced IL-8 secretion compared with stimulation with TNF- $\alpha$ alone, without a human milk factor pretreatment $(\square)$. (b) Results in the nontransformed fetal small IEC line, H4. *Statistical significance at $p<0.05$ for inhibition by TGF- $\beta 1$ and Epo and accentuated stimulation by EGF of TNF- $\alpha$-induced IL- 8 secretion compared with stimulation with TNF- $\alpha$ alone, without a human milk factor pretreatment $(\square)$.
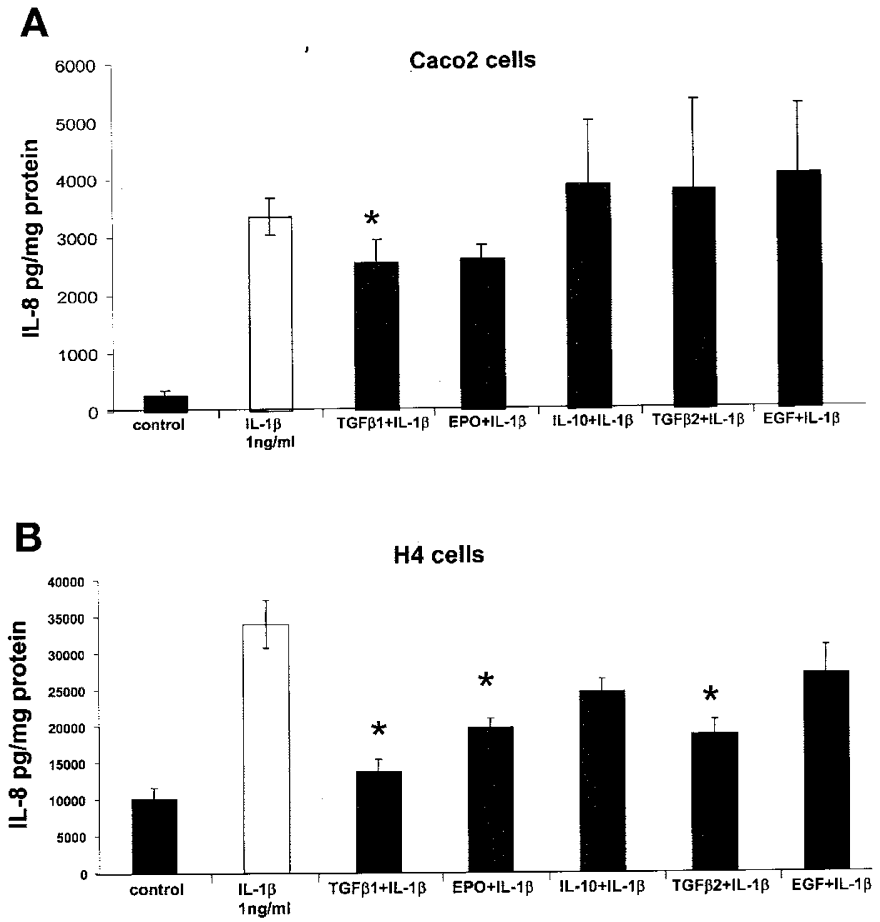

Figure 3. Effect of the human milk factors on IL- $1 \beta$-stimulated IL- 8 secretion by human IEC. Cells were pretreated with various factors for $24 \mathrm{~h}$ before stimulation with IL-1 $\beta$ ( $1 \mathrm{ng} / \mathrm{mL}$ for $24 \mathrm{~h})$. IL- 8 was measured by ELISA and compared with measured protein concentrations from cell lysates. Findings are presented \pm SEM; $n \geq 4$. (a) Results in the transformed adult colonic cell line Caco2. *Statistical significance at $p<0.05$ for inhibition by TGF- $\beta 1$ of IL- $1 \beta$-induced IL-8 secretion compared with stimulation with IL- $1 \beta$ alone, without a human milk factor pretreatment $(\square)$. (b) Results in the nontransformed fetal small IEC line H4. *Statistical significance at $p<0.05$ for inhibition by TGF- $\beta 1$, Epo, and TGF- $\beta 2$ of IL- $1 \beta$-induced IL- 8 secretion compared with stimulation with IL- $\beta$ alone, without a human milk factor pretreatment $(\square)$.

temperature-sensitive SV40 oncogene promotor at $32^{\circ} \mathrm{C}$ but becomes a nontransformed cell line at $37^{\circ} \mathrm{C}$ when the SV40 promotor is inactivated. However, the cell line grows slowly at $32^{\circ} \mathrm{C}$, limiting the number of possible observations; thus, it was used only to qualitatively confirm previous results. At $32^{\circ} \mathrm{C}$, the tsFHI cells produced $7800 \pm 2200 \mathrm{pg} / \mathrm{mg}$ protein IL-8 at baseline, $31000 \pm 17000 \mathrm{pg} / \mathrm{mg}$ protein IL-8 when stimulated by TNF- $\alpha$, and $24000 \pm 3100 \mathrm{pg} / \mathrm{mg}$ protein IL- 8 when stimulated by IL- $1 \beta$. At $37^{\circ} \mathrm{C}, 92000 \pm 8500 \mathrm{pg} / \mathrm{mg}$ protein IL-8 was secreted at baseline, $221000 \pm 143000$ $\mathrm{pg} / \mathrm{mg}$ protein IL-8 in response to TNF- $\alpha$, and $248000 \pm$ $18000 \mathrm{pg} / \mathrm{mg}$ protein IL-8 in response to IL-1 $\beta$ (Fig. 1). As shown in Fig. 1, the fetal small intestinal cell lines consistently produced more IL- 8 when stimulated by either TNF- $\alpha$ or IL-1 $\beta$ than the adult cell line of comparison. Interestingly, the nontransformed tsFHI cell line $\left(37^{\circ} \mathrm{C}\right)$ secreted more IL- 8 than the transformed tsFHI cell line $\left(32^{\circ} \mathrm{C}\right)$.

Growth factor studies using the nontransformed tsFHI cells at $37^{\circ} \mathrm{C}$ qualitatively confirmed findings in $\mathrm{H} 4$ cells. TGF- $\beta$ and Epo inhibited TNF- $\alpha$-stimulated IL- 8 secretion, and TGF$\beta 1$, Epo, and TGF- $\beta 2$ inhibited IL- $1 \beta$-stimulated IL- 8 secretion in tsFHI cells. 


\section{DISCUSSION}

These studies provide the first direct in vitro evidence of the anti-inflammatory effects of specific factors found in human milk on human fetal IEC. Although cell culture findings have limitations and need to be confirmed in in vivo models before findings are extrapolated to a disease entity, these findings in human cell culture models suggest a potentially important aspect of the protective effect of human milk against NEC. Although these factors are normally presented to the intestine in combination with the variety of factors found in human milk, these data represent an important first step toward understanding the actions in vitro of isolated growth factors that may potentially be useful as therapeutic agents. One difficulty in studying NEC at the IEC level has been the lack of an appropriate human model. Although animal models exist to study this disease as a whole, it is difficult to separate out effects specifically on the intestinal epithelium. IEC lines that have previously been used include rat small intestinal cell lines such as IEC-6 or human adult, colonic, transformed cell lines such as T84, Caco2, and HT29, even though NEC is a disease of the small intestine of preterm infants. $\mathrm{H} 4$ and tsFHI cell lines are derived from human fetal small intestine and may therefore be more representative of the susceptible preterm intestinal epithelium (30). We thus choose to compare effects in these cell lines to those of traditionally studied HT29-c119A and $\mathrm{Caco} 2$ cells, which are considered to have characteristics of mature enterocytes at confluence $(29,45-47)$.

We have previously hypothesized that an immature gastrointestinal tract places a preterm infant at higher risk for NEC (7). Although many risk factors have been noted for NEC, including feeding patterns, amino acid profiles, and ischemia, the primary risk factor is prematurity $(48-50)$. The pathophysiology of NEC is poorly understood and complex; thus, we have chosen to focus on the risk factor of prematurity and immaturity of the preterm intestine. One aspect of this immaturity is an exaggerated inflammatory response by IEC to microbial interaction that can produce a cascade resulting in systemic shock and death. In our studies, IL-8 secretion was induced by either TNF- $\alpha$ or IL- $1 \beta$. Both of these mediators are known to be elevated in infants with NEC and are strong endogenous inflammatory stimulants via the activation of nuclear factor $\kappa \mathrm{B}(\mathrm{NF}-\kappa \mathrm{B})$ leading to the increased production of many cytokines, one of which is IL-8 $(16,51-53)$. Our data demonstrate that fetal IEC have an increased TNF- $\alpha$ - and IL- $1 \beta$-stimulated IL-8 production compared with adult enterocytes. As shown in Fig. 1, IL-8 secretion in the fetal enterocyte cell lines $\mathrm{H} 4$ and tsFHI at either $32^{\circ} \mathrm{C}$ (transformed) or $37^{\circ} \mathrm{C}$ (nontransformed) was significantly increased compared with the transformed adult colonic cell lines HT29-cl19A and Caco2. Thus, the difference is not completely explained by transformed versus nontransformed. This finding is consistent with that from a previous publication from our laboratory demonstrating increased lipopolysaccharide/butyrate and IL$1 \beta$-stimulated IL-8 secretion in fetal IEC and organ culture compared with adult IEC and organ culture of intestinal tissue from older children (2). Importantly, this publication demonstrated that the $\mathrm{H} 4$ versus $\mathrm{Caco} 2$ cell line comparison is comparable to fetal versus older child tissue organ culture comparison, validating use of our cell culture model for the study of development of inflammatory responses in intestinal epithelial cells. Our data also potentially suggest that the immature intestine has an elevated baseline inflammatory state.

The pathophysiology of NEC is not completely understood, and therapy is currently only supportive. Means of preventing this disease or treating it in its early stages is needed. Human milk has been shown to be protective, although the mechanism of this protection is unknown and likely multifactorial (10). Thus, we next investigated the effect of specific factors found in human milk on stimulated IL-8 secretion in IEC. Five factors found in human milk were tested-TGF- $\beta 1$, TGF- $\beta 2$, Epo, IL-10, and EGF. These factors were selected because they had previously been shown to have anti-inflammatory effects in other model systems and/or to have a potentially protective role in NEC (24-28).

TGF- $\beta 1$ and Epo inhibited TNF- $\alpha$-stimulated IL-8 secretion to near control levels in human fetal IEC. This effect was not seen in the adult cell line HT29-cl19A. Similarly, TGF- $\beta 1$ and Epo significantly inhibited IL- $1 \beta$-stimulated IL-8 secretion in human fetal IEC, to a greater degree than in Caco2 cells. In addition, TGF- $\beta 2$, the predominant TGF- $\beta$ isoform in human milk and amniotic fluid, inhibited IL- $1 \beta$-stimulated IL- 8 secretion exclusively in the human fetal IEC cell line H4. These potentially beneficial effects are in addition to other protective effects on the intestine demonstrated by these growth factors in other studies.

TGF- $\beta$ maintains the integrity of the gastrointestinal barrier and furthermore has been shown to stimulate migration of cells across an injured epithelial monolayer, suggesting a role in restitution of the epithelium after injury (54). It is also an anti-inflammatory cytokine, as TGF- $\beta$ null mice survive during milk feeding but die after weaning from an extensive inflammatory disorder (25). The role of Epo has been less well characterized in the intestine, although Epo receptors have been demonstrated on human fetal and postnatal intestine. Epo has been shown to decrease TNF- $\alpha$-induced IEC apoptosis (35). Interestingly a retrospective study of preterm infants showed a decreased incidence of NEC in infants given Epo compared with infants who did not receive Epo (27). Human milk may provide necessary factors for the preterm infant in the extrauterine environment in the same way that amniotic fluid provides for the fetus in the uterine environment (55). Indeed, other preliminary unpublished observations from this laboratory have indicated that incubating $\mathrm{H} 4$ cells with amniotic fluid decreases TNF- $\alpha$ - and IL- $1 \beta$-stimulated IL- 8 secretion and that this effect is blocked by anti-TGF- $\beta$ and anti-Epo antibodies, again suggesting that these are potentially important anti-inflammatory factors for the fetal intestine (E. Claud, unpublished observations). These studies are ongoing.

The mechanism by which IL- 8 secretion was decreased is not clear. In IEC, after receptor activation, TNF- $\alpha$ and IL- $1 \beta$ can induce IL-8 secretion via pathways that use various adaptor molecules leading to NF- $\kappa \mathrm{B}$ activation. Thus, the studied factors could alter receptor expression or induce maturation of a signal transduction pathway. Alternatively, an immature pathway may exist in the $\mathrm{H} 4$ cell, which accentuates IL-8 production, but is turned off with maturation of the intestinal 
epithelium. Another possibility is that with maturation an alternate down-regulatory pathway that results in steps that inhibit NF- $\kappa$ B activation develops. Bocker et al. (42) demonstrated that differentiation of IEC selectively inhibits $\mathrm{NF}-\kappa \mathrm{B}$ activation in response to IL- $1 \beta$, which may represent an important regulatory mechanism. Studies of receptor expression and postreceptor signaling pathways in the adult and fetal cell lines are currently under investigation in our laboratory. It is not surprising that transformed cells are less responsive to growth factors such as TGF- $\beta$, as unregulated proliferation without differentiation is often a hallmark of carcinoma cells. Furthermore, it is known that TGF- $\beta$ postreceptor signaling is disrupted in many carcinoma cell lines as a result of alterations in Smad expression, the unique family of proteins that act as second messengers for the TGF- $\beta$ family of receptors (56-59).

The next factor that we examined, IL-10, unexpectedly did not inhibit IL-8 secretion in H4 cells, although there was an inhibition of TNF- $\alpha$-stimulated IL- 8 secretion in HT29-c119A cells consistent with findings from other studies. Because IL-10-deficient mice develop chronic enterocolitis and patients with Crohn's disease have shown improvement when treated with IL-10, we expected an anti-inflammatory effect $(26,36,60)$. A study comparing preterm to term infants with lung disease showed that preterm infants had minimal IL-10 protein or mRNA despite comparable inflammation to term infants, specifically suggesting a developmental difference in the role of IL-10 and inflammation (61). The authors suggested that immature preterm infants are unable to control the inflammatory process as effectively as more mature term infants, which may explain why in the first $96 \mathrm{~h}$ of life, neutrophil counts and IL- 8 expression decrease in term but not preterm infant bronchial lavage samples. They speculate that this may explain why preterm infants develop chronic lung disease, whereas term infants do not. We wondered whether a comparable immaturity of IL-10 production might lead to an increased inflammatory response in the preterm intestine. Our data suggest that in immature IEC, IL-10 does not directly inhibit TNF- $\alpha$ - or IL- $1 \beta$-induced IL- 8 secretion. IL-10 may affect cells other than epithelial cells, such as intestinal macrophages, or possibly affect epithelial cells indirectly via a two-step process. Alternatively, the absence of an IL-10 response with $\mathrm{H} 4$ cells may represent a developmental lack of response. A difference in receptor expression or postreceptor signaling pathways with maturation may explain why adult cells do have a decreased IL- 8 production with IL-10 pretreatment but immature IEC do not.

Perhaps the most surprising finding was the increased IL-8 secretion when cells were pretreated with EGF before TNF- $\alpha$ stimulation. EGF has been studied extensively in the intestine. EGF receptors are present throughout the gastrointestinal tract on the basolateral membrane, which may be more accessible in the preterm intestine with increased permeability $(62,63)$. It promotes intestinal growth and stimulates intestinal repair (64, 65). EGF levels are decreased in the saliva, serum, and urine of patients with NEC versus nondiseased age-matched controls, and a recent study showed a decreased incidence and severity of NEC in a rat model treated with $\operatorname{EGF}(28,66)$. There has also been a case report of an infant with enterocolitis improv- ing after treatment with i.v. EGF (67). Thus, we hypothesized that EGF would decrease stimulated IL-8 secretion.

The increased production of IL- 8 in response to EGF is not well explained. A recent paper described a pathway in IEC used by Gram-positive bacteria, which stimulates NF- $\kappa \mathrm{B}$ via the EGF receptor (68). This pathway is separate from the toll receptor linked pathways used by Gram-negative organisms to up-regulate production of inflammatory mediators via NF- $\kappa \mathrm{B}$ and may represent a mechanism by which EGF can up-regulate IL-8 production. Alternatively, EGF may up-regulate receptor number as described for the IL-1 receptor in other cell types (69). It is possible that other factors in human milk modulate this EGF response so that it is not proinflammatory when introduced to the intestine as part of complete human milk; however, these findings should prompt caution. Additional studies are required before using this factor as an isolated therapeutic agent to prevent NEC in humans.

\section{CONCLUSIONS}

In conclusion, we have demonstrated that $\mathrm{H} 4$ cells have a greater IL-8 response to both TNF- $\alpha$ and IL- $1 \beta$ than HT29cl19A or Caco2 cells. As a fetal small intestinal nontransformed cell line, H4 may be a better model for the study of enterocyte responses as they relate to NEC. In H4 and nontransformed tsFHI cells $\left(37^{\circ} \mathrm{C}\right)$, TGF- $\beta 1$ and Epo decreased both TNF- $\alpha$ - and IL- $1 \beta$-induced IL- 8 secretion and may have therapeutic implications, whereas EGF increased TNF- $\alpha-$ stimulated IL- 8 secretion. Outlining the mechanisms behind these effects is the focus of ongoing studies.

We have previously suggested that the injury in NEC may result from colonization of the uniquely susceptible premature intestine with pathogenic bacteria resulting in an exaggerated inflammatory response (7). TGF- $\beta$ and Epo potentially decrease this exaggerated inflammatory response specifically in human fetal IEC. This effect may partially explain the protective effect of human milk in necrotizing enterocolitis.

\section{REFERENCES}

1. Molmenti EP, Ziambaras T, Perlmutter DH 1993 Evidence for an acute phase response in human intestinal epithelial cells. J Biol Chem 268:14116-14124

2. Nanthakumar NN, Fusunyan RD, Sanderson I, Walker WA 2000 Inflammation in the developing human intestine: a possible pathophysiologic contribution to necrotizing enterocolitis. Proc Natl Acad Sci U S A 97:6043-6048

3. Sanderson IR, Xu Z, Chu SW, Xie QY, Levine LJ, Walker WA 1996 Developmental differences in the expression of the cholera toxin sensitive subunit (Gs alpha) of adenylate cyclase in the rat small intestine. Gut 38:853-858

4. Stadnyk AW 1994 Cytokine production by epithelial cells. FASEB J 8:1041-1047

5. Chu SH, Walker WA 1993 Bacterial toxin interaction with the developing intestine. Gastroenterology 104:916-925

6. Ciarlet M, Conner ME, Finegold MJ, Estes MK 2002 Group A rotavirus infection and age-dependent diarrheal disease in rats: a new animal model to study the pathophysiology of rotavirus infection. J Virol 76:41-57

7. Claud EC, Walker WA 2001 Hypothesis: inappropriate colonization of the premature intestine can cause neonatal necrotizing enterocolitis. FASEB J 15:1398-1403

8. Udall Jr JN 1990 Gastrointestinal host defense and necrotizing enterocolitis. J Pediatr 117:S33-S43

9. Grazioso CF, Werner AL, Alling DW, Bishop PR, Buescher ES 1997 Antiinflammatory effects of human milk on chemically induced colitis in rats. Pediatr Res 42:639-643

10. Lucas A, Cole TJ 1990 Breast milk and neonatal necrotizing enterocolitis. Lancet 336:1519-1523

11. Newburg DS 2000 Oligosaccharides in human milk and bacterial colonization. J Pediatr Gastroenterol Nutr 30:S8-S17

12. Goldman AS, Garza C, Nichols BL, Goldblum RM 1982 Immunologic factors in human milk during the first year of lactation. J Pediatr 100:563-567

13. Goldman AS, Goldblum RM, Hanson LA 1990 Anti-inflammatory systems in human milk. Adv Exp Med Biol 262:69-76 
14. Moya FR, Eguchi H, Zhao B, Furukawa M, Sfeir J, Osorio M, Ogawa Y, Johnston JM 1994 Platelet-activating factor acetylhydrolase in term and preterm human milk: preliminary report. J Pediatr Gastroenterol Nutr 19:236-239

15. Bernt KM, Walker WA 1999 Human milk as a carrier of biochemical messages. Acta Paediatr Suppl 88:27-41

16. Edelson MB, Bagwell CE, Rozycki HJ 1999 Circulating pro- and counterinflammatory cytokine levels and severity in necrotizing enterocolitis. Pediatrics 103:766-771

17. Caplan MS, Sun XM, Hseuh W, Hageman JR 1990 Role of platelet activating facto and tumor necrosis factor-alpha in neonatal necrotizing enterocolitis. J Pediatr 116:960-964

18. Kosloske AM 1994 Epidemiology of necrotizing enterocolitis. Acta Paediatr Suppl 396:2-7

19. Musemeche C, Caplan M, Hsueh W, Sun X, Kelly A 1991 Experimental necrotizing enterocolitis: the role of polymorphonuclear neutrophils. J Pediatr Surg 26:10471049; discussion 1049-1050

20. Baggiolini M, Walz A, Kunkel SL 1989 Neutrophil-activating peptide-1/interleukin 8, a novel cytokine that activates neutrophils. J Clin Invest 84:1045-1049

21. Djeu JY, Matsushima K, Oppenheim JJ, Shiotsuki K, Blanchard DK 1990 Functiona activation of human neutrophils by recombinant monocyte-derived neutrophil chemotactic factor/IL-8. J Immunol 144:2205-2210

22. Huber AR, Kunkel SL, Todd 3rd RF, Weiss SJ 1991 Regulation of transendothelial neutrophil migration by endogenous interleukin-8. Science 254:99-102

23. Nadler EP, Stanford A, Zhang XR, Schall LC, Alber SM, Watkins SC, Ford HR 2001 Intestinal cytokine gene expression in infants with acute necrotizing enterocolitis: interleukin-11 mRNA expression inversely correlates with extent of disease. J Pediat Surg 36:1122-1129

24. Lane JS, Todd KE, Lewis MP, Gloor B, Ashley SW, Reber HA, McFadden DW, Chandler CF 1997 Interleukin-10 reduces the systemic inflammatory response in a murine model of intestinal ischemia/reperfusion. Surgery 122:288-294

25. Kulkarni AB, Karlsson S 1993 Transforming growth factor-beta 1 knockout mice. A mutation in one cytokine gene causes a dramatic inflammatory disease. Am J Patho 143:3-9

26. Kuhn R, Lohler J, Rennick D, Rajewsky K, Muller W 1993 Interleukin-10-deficient mice develop chronic enterocolitis. Cell 75:263-274

27. Ledbetter DJ, Juul SE 2000 Erythropoietin and the incidence of necrotizing enterocolitis in infants with very low birth weight. J Pediatr Surg 35:178-181; discussion 182

28. Dvorak B, Halpern MD, Holubec H, Williams CS, McWilliam DL, Dominguez JA, Stepankova R, Payne CM, McCuskey RS 2002 Epidermal growth factor reduces the development of necrotizing enterocolitis in a neonatal rat model. Am J Physio 282:G156-G164

29. Augeron C, Laboisse CL 1984 Emergence of permanently differentiated cell clones in a human colonic cancer cell line in culture after treatment with sodium butyrate. Cancer Res 44:3961-3969

30. Sanderson IR, Ezzell RM, Kedinger M, Erlanger M, Xu ZX, Pringault E, LeonRobine S, Louvard D, Walker WA 1996 Human fetal enterocytes in vitro: modulation of the phenotype by extracellular matrix. Proc Natl Acad Sci U S A 93:7717-7722

31. Quaroni A, Beaulieu JF 1997 Cell dynamics and differentiation of conditionally immortalized human intestinal epithelial cells. Gastroenterology 113:1198-1213

32. Saito S, Yoshida M, Ichijo M, Ishizaka S, Tsujii T 1993 Transforming growth factor-beta (TGF-beta) in human milk. Clin Exp Immunol 94:220-224

33. Bry K, Hallman M 1992 Transforming growth factor-beta opposes the stimulatory effects of interleukin-1 and tumor necrosis factor on amnion cell prostaglandin E2 production: implication for preterm labor. Am J Obstet Gynecol 167:222-226

34. Ostlund E, Lindholm H, Hemsen A, Fried G 2000 Fetal erythropoietin and endothelin-1: relation to hypoxia and intrauterine growth retardation. Acta Obstet Gynecol Scand 79:276-282

35. Juul SE, Joyce AE, Zhao Y, Ledbetter DJ 1999 Why is erythropoietin present in human milk? Studies of erythropoietin receptors on enterocytes of human and rat neonates. Pediatr Res 46:263-268

36. Schottelius AJ, Mayo MW, Sartor RB, Baldwin Jr AS 1999 Interleukin-10 signaling blocks inhibitor of kappaB kinase activity and nuclear factor kappaB DNA binding. J Biol Chem 274:31868-31874

37. Pender SL, Breese EJ, Gunther U, Howie D, Wathen NC, Schuppan D, MacDonal TT 1998 Suppression of T cell-mediated injury in human gut by interleukin 10: role of matrix metalloproteinases. Gastroenterology 115:573-583

38. Moran JR, Courtney ME, Orth DN, Vaughan R, Coy S, Mount CD, Sherrell BJ, Greene HL 1983 Epidermal growth factor in human milk: daily production and diurnal variation during early lactation in mothers delivering at term and at premature gestation. J Pediatr 103:402-405

39. Zijlstra RT, Odle J, Hall WF, Petschow BW, Gelberg HB, Litov RE 1994 Effect of orally administered epidermal growth factor on intestinal recovery of neonatal pigs infected with rotavirus. J Pediatr Gastroenterol Nutr 19:382-390

40. Levy E, Thibault L, Menard D 1992 Intestinal lipids and lipoproteins in the human fetus: modulation by epidermal growth factor. J Lipid Res 33:1607-1617

41. Eckmann L, Jung HC, Schurer-Maly C, Panja A, Morzycka-Wroblewska E, Kagnoff MF 1993 Differential cytokine expression by human intestinal epithelial cell lines: regulated expression of interleukin 8. Gastroenterology 105:1689-1697

42. Bocker U, Schottelius A, Watson JM, Holt L, Licato LL, Brenner DA, Sartor RB, Jobin C 2000 Cellular differentiation causes a selective down-regulation of interleukin (IL) $-1 \beta$-mediated NF- $\kappa \mathrm{B}$ activation and IL-8 gene expression in intestinal epithelia cells. J Biol Chem 275:12207-12213

43. Gewirtz AT, Siber AM, Madara JL, McCormick BA 1999 Orchestration of neutrophil movement by intestinal epithelial cells in response to Salmonella typhimurium can be uncoupled from bacterial internalization. Infect Immun 67:608-617
44. Roberts AB, Sporn MB 1992 Differential expression of the TGF-beta isoforms in embryogenesis suggests specific roles in developing and adult tissues. Mol Reprod Dev 32:91-98

45. Mariadason JM, Velcich A, Wilson AJ, Augenlicht LH, Gibson PR 2001 Resistance to butyrate-induced cell differentiation and apoptosis during spontaneous Caco-2 cell differentiation. Gastroenterology 120:889-899

46. Niv Y, Byrd JC, Ho SB, Dahiya R, Kim YS 1992 Mucin synthesis and secretion in relation to spontaneous differentiation of colon cancer cells in vitro. Int $\mathrm{J}$ Cancer 50:147-152

47. Chantret I, Barbat A, Dussaulx E, Brattain MG, Zweibaum A 1988 Epithelial polarity, villin expression, and enterocytic differentiation of cultured human colon carcinoma cells: a survey of twenty cell lines. Cancer Res 48:1936-1942

48. Halac E, Halac J, Begue EF, Casanas JM, Indiveri DR, Petit JF, Figueroa MJ, Olmas JM, Rodriguez LA, Obregon RJ, et al 1990 Prenatal and postnatal corticosteroid therapy to prevent neonatal necrotizing enterocolitis: a controlled trial. J Pediatr 117:132-138

49. Caplan MS, MacKendrick W 1993 Necrotizing enterocolitis: a review of pathogenetic mechanisms and implications for prevention. Pediatr Pathol 13:357-369

50. Kamitsuka MD, Horton MK, Williams MA 2000 The incidence of necrotizing enterocolitis after introducing standardized feeding schedules for infants between 1250 and 2500 grams and less than 35 weeks of gestation. Pediatrics 105:379-384

51. Viscardi RM, Lyon NH, Sun CC, Hebel JR, Hasday JD 1997 Inflammatory cytokine mRNAs in surgical specimens of necrotizing enterocolitis and normal newborn intestine. Pediatr Pathol Lab Med 17:547-559

52. Tan X, Hsueh W, Gonzalez-Crussi F 1993 Cellular localization of tumor necrosis factor (TNF)-alpha transcripts in normal bowel and in necrotizing enterocolitis. TNF gene expression by Paneth cells, intestinal eosinophils, and macrophages. Am J Pathol 142:1858-1865

53. Jobin C, Holt L, Bradham CA, Streetz K, Brenner DA, Sartor RB 1999 TNF receptor-associated factor- 2 is involved in both IL-1 beta and TNF-alpha signaling cascades leading to NF-kappa B activation and IL-8 expression in human intestinal epithelial cells. J Immunol 162:4447-4454

54. Ciacci C, Lind SE, Podolsky DK 1993 Transforming growth factor beta regulation of migration in wounded rat intestinal epithelial monolayers. Gastroenterology 105:93-101

55. Wagner CL 2002 Amniotic fluid and human milk: a continuum of effect? J Pediatr Gastroenterol Nutr 34:513-514

56. Lee S, Cho YS, Shim C, Kim J, Choi J, Oh S, Zhang W, Lee J 2001 Aberrant expression of Smad4 results in resistance against the growth-inhibitory effect of transforming growth factor-beta in the SiHa human cervical carcinoma cell line. Int J Cancer 94:500-507

57. Xie W, Mertens JC, Reiss DJ, Rimm DL, Camp RL, Haffty BG, Reiss M 2002 Alterations of Smad signaling in human breast carcinoma are associated with poor outcome: a tissue microarray study. Cancer Res 62:497-505

58. Woodford-Richens KL, Rowan AJ, Gorman P, Halford S, Bicknell DC, Wasan HS, Roylance RR, Bodmer WF, Tomlinson IP 2001 SMAD4 mutations in colorectal cancer probably occur before chromosomal instability, but after divergence of the microsatellite instability pathway. Proc Natl Acad Sci U S A 98:9719-9723

59. Ahmed MM, Alcock RA, Chendil D, Dey S, Das A, Venkatasubbarao K, Mohiuddin M, Sun L, Strodel WE, Freeman JW 2002 Restoration of transforming growth factor-beta signaling enhances radiosensitivity by altering the Bcl-2/Bax ratio in the p53 mutant pancreatic cancer cell line MIA PaCa-2. J Biol Chem 277:2234-2246

60. van Deventer SJ, Elson CO, Fedorak RN 1997 Multiple doses of intravenous interleukin 10 in steroid-refractory Crohn's disease. Crohn's Disease Study Group. Gastroenterology 113:383-389

61. Jones CA, Cayabyab RG, Kwong KY, Stotts C, Wong B, Hamdan H, Minoo P, deLemos RA 1996 Undetectable interleukin (IL)-10 and persistent IL-8 expression early in hyaline membrane disease: a possible developmental basis for the predisposition to chronic lung inflammation in preterm newborns. Pediatr Res 39:966-975

62. Fagbemi AO, Wright N, Lakhoo K, Edwards AD 2001 Immunoreactive epidermal growth factor receptors are present in gastrointestinal epithelial cells of preterm infants with necrotising enterocolitis. Early Hum Dev 65:1-9

63. Menard D, Pothier P 1991 Radioautographic localization of epidermal growth factor receptors in human fetal gut. Gastroenterology 101:640-649

64. Swaniker F, Guo W, Fonkalsrud EW, Diamond J 1995 The effect of epidermal growth factor on mucosal function after ileal resection. J Surg Res 58:565-569

65. Miettinen PJ, Berger JE, Meneses J, Phung Y, Pedersen RA, Werb Z, Derynck R 1995 Epithelial immaturity and multiorgan failure in mice lacking epidermal growth factor receptor. Nature 376:337-341

66. Shin CE, Falcone Jr RA, Stuart L, Erwin CR, Warner BW 2000 Diminished epidermal growth factor levels in infants with necrotizing enterocolitis. J Pediatr Surg 35:173-176; discussion 177

67. Sullivan PB, Brueton MJ, Tabara ZB, Goodlad RA, Lee CY, Wright NA 1991 Epidermal growth factor in necrotizing enteritis. Lancet 338:53-54

68. Lemjabbar H, Basbaum C 2002 Platelet-activating factor receptor and ADAM10 mediate responses to Staphylococcus aureus in epithelial cells. Nat Med 8:41-46

69. Bry K 1993 Epidermal growth factor and transforming growth factor-alpha enhance the interleukin-1- and tumor necrosis factor-stimulated prostaglandin E2 production and the interleukin-1 specific binding on amnion cells. Prostaglandins Leukot Essent Fatty Acids 49:923-928 